Editorial

\title{
Special Issue on Advancing Grid-Connected Renewable Generation Systems
}

\author{
Frede Blaabjerg * and Yongheng Yang * \\ Department of Energy Technology, Aalborg University, Pontoppidanstraede 111, DK9220 Aalborg, Denmark \\ * Correspondence: fbl@et.aau.dk (F.B.); yoy@et.aau.dk (Y.Y.)
}

Academic Editor: Takayoshi Kobayashi

Received: 18 May 2017; Accepted: 31 May 2017; Published: 3 June 2017

\section{Introduction}

Renewables are heavily involved in power generation, as an essential component for today's energy paradigm. Energy structure-both national and international-has been undergoing significant changes over the past few decades. For instance, in Denmark, power generation is shifting from fossil-fuel-based to renewable-based in terms of energy sources, from centralized to decentralized in terms of architectures, and from sole to miscellaneous in terms of energy varieties [1]. In this energy evolution, the power electronic technology plays an enabling role in the integration and advancements of renewables-such as wind turbine, photovoltaics, fuel cells, and other emerging energy systems. At the same time, various control strategies are necessary to guide the energy integration (i.e., to enhance the energy transition), and on the other hand, to flexibly, reliably, and efficiently utilize the energy. Tremendous application-driven power converters and control techniques for grid-connected renewables have been developed and more are coming into market to further secure the renewable power generation. Stringent demands from both utility system operators and consumers have also been (and are being) imposed on grid-connected renewable generation systems.

\section{Advanced Grid-Connected Renewables}

In light of the above, this special issue was introduced to collect latest research on relevant topics, and more importantly, to address present challenging issues with the integration of renewable energies in a sustainable and resilient power system. There were 39 papers submitted to this special issue, and 13 papers were accepted (i.e., 33\% acceptance rate). When looking back to the special issues, various topics have been addressed, mainly on energy storage, photovoltaic, and wind power technologies. The first paper, authored by L. Wu, X. Fu, and Y. Guan, presents a review of the remaining useful life prognostics of vehicle lithium-ion batteries [2], where the data-driven methodologies have been adopted. This is a timely overview article, since lithium-ion batteries are the primary power source in the booming electric vehicle industry. The second paper provides another review on flywheel energy storage technologies [3], authored by M. Amiryar and K. Pullen. Along with the fast development and exploitation of renewables, the role of energy storage systems is becoming essential [4], as also highlighted in the paper [3]. Additionally, Z. Liu, Y. Chen, Y. Luo, G. Zhao, and X. Jin address the optimal planning and utilization issues for various distributed generators and energy storage systems [5].

There are five papers focused on solar photovoltaic (PV) technologies-the first one by N. Tien and S. Shin introduced a novel concentrator PV system [6], which improves the irradiation uniformity and system efficiency. The second paper, authored by G. Brando, A. Dannier, A. Del Pizzo, and I. Spina, discusses the control and modulation techniques for a centralized PV system using interleaved inverters [7]. The third paper, authored by P. Guerriero, M. Coppola, F. Di Napoli, G. Brando, A. Dannier, D. Iannuzzi, and S. Daliento, presents the design of a three-phase grid-connected PV 
cascaded H-bridge inverter [8]. The fourth one introduces a detailed probabilistic reliability model for a PV system [9], authored by A. Alferidi and R. Karki. The last paper about the PV technologies was authored by Z. Zhang, Y. Yang, R. Ma, and F. Blaabjerg, where the zero-voltage ride-through capability for single-phase grid-connected PV systems is analyzed [10]. The study was dedicated to improving the performance of the grid under zero-voltage faults in the case of a wide-scale adoption of PV systems. Additionally, two papers discussed the integration issues of wind power systems-the first one, by M. Bandi and J. Apt, addresses the variability of the wind-turbine power curve [11]. The method introduced in this paper can account for both environmental and plant-induced sources of variability, which would potentially reduce wind power forecast uncertainty. The other paper, authored by J. Tian, D. Zhou, C. Su, F. Blaabjerg, and Z. Chen, focuses on the system performance of wind farms. An optimal active power control method has been introduced [12], which results in increased energy production. The wake effect and lifetime of power converters are also considered in this paper.

As an emerging renewable energy technology, there is intensive research on wave/marine energy, but more should come. In this special issue, two papers put the focus on this technology. The first one, authored by S. Song and J. Park, presents a control strategy for an impulse turbine for an oscillating water column-wave energy converter [13]. Stability analysis has been performed based on the Lyapunov method. In the other paper, authored by S. Song, Y. Sung, and J. Park, the modelling of a wave energy converter was introduced [14], and simulations were presented. The model developed in this paper can be adopted for further study in wave energy.

Lastly, the paper 'Overload Control in Smart Transformer-Fed Grid' introduces overload control strategies for smart transformers. The paper was authored by G. De Carne, Z. Zou, G. Buticchi, M. Liserre, and C. Vournas. In this paper, the authors first highlight the challenges in the case of adopting massive renewable energy resources. Smart transformer technology provides a promising solution to managing energy as well as to providing ancillary services to improve the grid [15]. However, a limited overload capability becomes the major drawback for smart transformers, which has been discussed in this paper.

\section{Future Renewable Energies}

Although the special issue has been closed, more in-depth research in renewable energy technologies is expected. It can be anticipated that more friendly and pollution-free energies will be demanded in large numbers in the future for sustainable societies. In this case, appropriate control strategies should be ready for integration and utilization.

Acknowledgments: This issue would not be possible without the contributions of various talented authors, hardworking and professional reviewers, and dedicated editorial team of Applied Sciences. Congratulations to all authors-no matter what the final decisions of the submitted manuscripts were, the feedback, comments, and suggestions from the reviewers and editors helped the authors to improve their papers. We would like to take this opportunity to record our sincere gratefulness to all reviewers. Finally, we place on record our gratitude to the editorial team of Applied Sciences, and special thanks to Jennifer Li, Assistant Editor and Xiaoyan Chen, Senior Assistant Editor, both from MDPI Branch Office, Beijing.

\section{References}

1. Blaabjerg, F.; Yang, Y.; Yang, D.; Wang, X. Distributed Power-Generation Systems and Protection. Proc. IEEE 2017, 105, 1-21. [CrossRef]

2. Wu, L.; Fu, X.; Guan, Y. Review of the Remaining Useful Life Prognostics of Vehicle Lithium-Ion Batteries Using Data-Driven Methodologies. Appl. Sci. 2016, 6, 166. [CrossRef]

3. Amiryar, M.; Pullen, K. A Review of Flywheel Energy Storage System Technologies and Their Applications. Appl. Sci. 2017, 7, 286. [CrossRef]

4. Barton, J.P.; Infield, D.G. Energy storage and its use with intermittent renewable energy. IEEE Trans. Energy Convers. 2004, 19, 441-448. [CrossRef] 
5. Liu, Z.; Chen, Y.; Luo, Y.; Zhao, G.; Jin, X. Optimized Planning of Power Source Capacity in Microgrid, Considering Combinations of Energy Storage Devices. Appl. Sci. 2016, 6, 416. [CrossRef]

6. Tien, N.; Shin, S. A Novel Concentrator Photovoltaic (CPV) System with the Improvement of Irradiance Uniformity and the Capturing of Diffuse Solar Radiation. Appl. Sci. 2016, 6, 251. [CrossRef]

7. Brando, G.; Dannier, A.; del Pizzo, A.; Spina, I. Control and Modulation Techniques for a Centralized PV Generation System Grid Connected via an Interleaved Inverter. Appl. Sci. 2016, 6, 261. [CrossRef]

8. Guerriero, P.; Coppola, M.; di Napoli, F.; Brando, G.; Dannier, A.; Iannuzzi, D.; Daliento, S. Three-Phase PV CHB Inverter for a Distributed Power Generation System. Appl. Sci. 2016, 6, 287. [CrossRef]

9. Alferidi, A.; Karki, R. Development of Probabilistic Reliability Models of Photovoltaic System Topologies for System Adequacy Evaluation. Appl. Sci. 2017, 7, 176. [CrossRef]

10. Zhang, Z.; Yang, Y.; Ma, R.; Blaabjerg, F. Zero-Voltage Ride-Through Capability of Single-Phase Grid-Connected Photovoltaic Systems. Appl. Sci. 2017, 7, 315. [CrossRef]

11. Bandi, M.; Apt, J. Variability of the Wind Turbine Power Curve. Appl. Sci. 2016, 6, 262. [CrossRef]

12. Tian, J.; Zhou, D.; Su, C.; Blaabjerg, F.; Chen, Z. Optimal Control to Increase Energy Production of Wind Farm Considering Wake Effect and Lifetime Estimation. Appl. Sci. 2017, 7, 65. [CrossRef]

13. Song, S.; Park, J. Control Strategy of an Impulse Turbine for an Oscillating Water Column-Wave Energy Converter in Time-Domain Using Lyapunov Stability Method. Appl. Sci. 2016, 6, 281. [CrossRef]

14. Song, S.; Sung, Y.; Park, J. Modeling and Simulation of a Wave Energy Converter INWAVE. Appl. Sci. 2017, 7, 99. [CrossRef]

15. De Carne, G.; Zou, Z.; Buticchi, G.; Liserre, M.; Vournas, C. Overload Control in Smart Transformer-Fed Grid. Appl. Sci. 2017, 7, 208. [CrossRef]

(C) 2017 by the authors. Licensee MDPI, Basel, Switzerland. This article is an open access article distributed under the terms and conditions of the Creative Commons Attribution (CC BY) license (http:/ / creativecommons.org/licenses/by/4.0/). 